DOI: https://doi.org/10.18485/bells.2016.8.17

821.111(73)-31.09 Jen G.

\author{
Sandra Josipović \\ University of Belgrade \\ Faculty of Philology \\ Serbia
}

\title{
THE TRANSFORMATION OF THE IMMIGRANT'S IDENTITY AND THE TRADITIONAL AND CONTEMPORARY CULTURAL CONCEPTS IN THE TRANSLATION OF GISH JEN'S SHORT STORIES
}

\begin{abstract}
Since Gish Jen was born to the Chinese immigrant parents in New York City, it is no wonder that her work provides a good insight into the immigrant's experience. With reference to Derrida's concepts of the arrivant and hospitality, the paper focuses on some issues that Gish Jen raises in her work: the transformation of the immigrant's identity in America, the interaction between the two cultures and cultural and identity clashes. The paper also focuses on the strategies used to translate into the Serbian language such a work that contains some Chinese culture-specific concepts and phrases.
\end{abstract}

Key words: tradition, culture, transformation, immigrant identity

\footnotetext{
Email address: harte@ptt.rs
} 


\section{Introduction}

The paper focuses on the issues that Gish Jen writes about in her collection of short stories Who's Irish?: the transformation of the Chinese immigrant's identity when he comes into contact with the American culture, the differences between the Chinese and American culture and how they influence and affect each other, the reaction of the Americans to Chinese immigrants, the cultural and identity clashes which occur when it comes to immigrant adapting to the life in America. These issues are viewed here in the light of Derrida's concepts of the arrivant or the 'newcomer' ${ }^{1}$ and hospitality. This paper also deals with the fact that some traditional and contemporary Chinese cultural concepts in Jen's stories may represent a challenge in literary translation and some strategies for dealing with this challenge are suggested.

Since Gish Jen writes about the American and Chinese culture that come into contact and interact, her stories illustrate what Edward Said wrote: "But the history of all cultures is the history of cultural borrowings. Cultures are not impermeable [...] Culture is never just a matter of ownership, of borrowing and lending with absolute debtors and creditors, but rather of appropriations, common experiences, and interdependencies of all kinds among different cultures. This is a universal norm" (Said 1994: 217). Derrida also connects culture and hospitality, saying that: "Hospitality is culture itself and not simply one ethic among others" (Westmoreland 2008: 3). Jeanne Sokolowski also used Derrida's concepts of hospitality and arrivant to address in Gish Jen's novel The Love Wife the issues the Chinese immigrants face in the United States, emphasizing that: "Derrida's

work on hospitality has been relatively underutilized within the field of Asian American Studies" (Sokolowski 2012).

\footnotetext{
1 Reverso: Online dictionary: French-English translation of words and expressions, definition, synonyms; Accessed April 16, 2016, http://dictionary.reverso.net/frenchenglish/arrivant.
} 
Sandra Josipović: The Transformation of the Immigrant's Identity...

\section{The immigrant as the arrivant and the transformation of the immigrant's identity}

When Derrida explains the concept of arrivant, he says:

One does not expect the event of whatever, of whoever comes, arrives, and crosses the threshold - the immigrant, the emigrant, the guest, or stranger. But if the new arrivant who arrives is new, one must expect - without waiting for him or her, without expecting it - that he does not simply cross a given threshold. Such an arrivant affects the very experience of the threshold, whose possibility he thus brings to light before one even knows whether there has been an invitation, a call, a nomination, or a promise [...] What we could here call the arrivant, the most arrivant among all arrivants [...] is whatever, whoever, in arriving, does not cross a threshold separating two identifiable places, the proper and the foreign, the proper of the one and the proper of the other [....] (Derrida 1993: 33-34)

It can be said that in Gish Jen's stories the arrivants are the Chinese immigrants who, as Derrida says, do not cross an already existing threshold, but they create a new one when they come to a new country by bringing with themselves the elements of their Chinese culture to America and trying to reconcile the elements of the Chinese and American cultures. Therefore, these immigrants do not separate two places, the one from which they are coming and the one to which they are coming. In the story "Who's Irish?", Gish Jen shows that the first-generation immigrants can adapt to a new country and transform their identity to a certain degree, but, at the same time, these immigrants very much rely on the old customs and traditions. In this story, an ageing Chinese mother who emigrated to America a long time ago and who is now sixty-eight (Jen 2000: 5) comes to live with her daughter, Nattie, the daughter's Irish-American husband, John, and their young daughter, Sophie. When she comes to America, the old lady doesn't speak English and doesn't have any money (Jen 2000: 4). But she learns some English and tries to adapt to the American way of life and as a result of that she manages to have her American dream and have her own restaurant business and no mortgage (Jen 2000: 4). At the same time she cannot wholly relinquish the old Chinese customs. The Chinese and American cultural concepts clash in her and she says: "In America, 
parents not supposed to spank the child" (Jen 2000: 9), whereas in China it is supposed to be done in order to teach a child not to misbehave (Jen 2000: 9). Then she says: "In China, daughter take care of mother. Here it is the other way around" (Jen 2000: 5). Then, as the old lady believes, "Chinese people don't think a daughter is so great" (Jen 2000: 7). But, her daughter's Irish-American mother-in-law has only sons and regrets not having a daughter (Jen 2000: 7), so it is apparently all right to have a daughter in America. The old lady also considers her granddaughter's Chinese side of her character to be "nice" and her Irish-American side to be "wild" (Jen 2000: 6).

As Derrida says, the arrivant doesn't simply cross the given threshold, but "an arrivant affects the very experience of the threshold" (Derrida 1993: 33), that is to say, in the story "House, House, Home" Pammie creates her own new threshold to cross when she marries Sven, her American husband. Sven and Pammie even physically, not only symbolically, cross a new threshold in their lives. In the story, when Sven asks her to come away with him for a weekend, which marks the beginning of their relationship: "He stepped off the brick path as he spoke, onto a small patch of gravel to let people pass. An archipelago of scrappy grass grew up through the stones. Pammie stepped off the path, too [...]" (Jen 2000: 145). They step over a newly created threshold into the unchartered territory for both of them. Pammie is the arrivant who, upon entering the marriage, creates and crosses a new threshold, trying to bring some elements of her Chinese culture to her American husband. She thinks she brings something new to her husband because he even becomes interested in Chinese art (Jen 2000: 164). But she realizes that crossing the threshold doesn't have the same meaning for her husband. He doesn't study Chinese art to be closer to her culture and heritage, it is simply something new to explore and to her it is the "proof that Sven had seen her as other, as not-self, as object to his subject, someone he expected to scrutinize, not to be scrutinized by" (Jen 2000: 165).

Derrida goes on to say:

No, I am talking about the absolute arrivant, who is not even a guest. He surprises the host - who is not yet a host or an inviting power - enough to call into question, to the point of annihilating or rendering indeterminate, all the distinctive signs of a prior identity, beginning with the very border that delineated a legitimate home and assured lineage, names and language, 
nations, families and genealogies. The absolute arrivant does not yet have a name or an identity. It is not an invader or an occupier, nor is it a colonizer, even if it can also become one (Derrida 1993: 34).

In her stories "Who's Irish?" and "Chin", Gish Jen writes that the immigrant always in a way surprises the host, as Derrida says, to the point that many things can be jeopardized: the identity of the host, the borders that determine the host's home and the host's concept of a family (Derrida 1993: 34). The immigrant does not come as an invader or an occupier, but sometimes he unintentionally becomes one (Derrida 1993: 34) as it is the case in the story "Who's Irish?". The Chinese mother is the arrivant who is not a guest in a true sense of the word because her daughter does not ask her mother to live with her out of a filial duty to her mother, but she asks her mother to live with her in order to have a free baby-sitter who will look after Sophie (Jen 2000: 5). On the other hand, the old lady thinks that according to Confucius's teachings, the young should look after their ageing parents. (Jen 2000: 3) Tatjana Andrejević says that Confucius's teachings:

still shape the mentality of the Chinese people (although these ideas were officially banned by the Communists) [...] The basic canons of Confucian thought are obedience to and respect for superiors and parents, duty to family, loyalty to friends, honesty, humility, sincerity and courtesy [...] Xiào (filial piety, "of a son") is considered among the greatest virtues and has to be shown towards both the living and the dead (Andrejević 2011: 282).

Derrida says that upon his arrival, the arrivant doesn't have an identity (Derrida 1993: 34). In this story, the daughter knows who her mother is, of course, but, she doesn't know what her mother really will be like when she comes to live with her. Therefore, as far as the daughter is concerned, her mother gains a new identity the moment she crosses the threshold of her home. It leads to the confrontation between the two women, to the confrontation between the old Chinese and the modern American view on life. For example, the Chinese grandmother goes to the park with her granddaughter. To the grandmother's utter astonishment, the three-yearold girl stands up in her stroller in the park and takes off all her clothes and throws them into the fountain. (Jen 2000: 8) We learn from the 
grandmother's story that Amy, who once babysat Sophie, encouraged her to do that, saying that the little girl "should love her body" (Jen 2000: 8).

The mother's arrival surprises Nattie, the host, in a sense that the mother makes Nattie defend her way of life, the way she brings up her own daughter Sophie and makes her defend her husband John who doesn't have a job and according to the old lady, the members of John's family are incapable of finding one (Jen 2000: 4). Nattie justifies her husband going to the gym frequently by saying that "he will be depressed (Jen 2000: 5)" and "no one wants to hire someone who is depressed" (Jen 2000: 5). When her husband finally finds a job, although he will not keep it for too long, she buys her husband "some special candy bars from the health-food store. They say THINK! on them, and are supposed to help John think" (Jen 2000: 6). When Nattie's little daughter Sophie misbehaves, she cannot deal with her because she has some big presentation at work the following day (Jen 2000: 9) and she forbids her mother to raise Sophie the way the old lady thinks she should. Nattie doesn't allow her mother to criticize her husband and tells her mother she shouldn't say "Irish this, Irish that." (Jen 2000: 3). But the old lady cannot help commenting on her son-in-law's flaws: "I especially cannot understand my daughter's husband John, who has no job but cannot take care of Sophie either. Because, he is a man, he say ..." (Jen 2000: 5). And finally she says to herself disapprovingly: "John lost his job again, already" (Jen 2000: 15). The old lady knows how to defend herself and her views and how to surprise her hosts with an outrageous remark. She doesn't like to hear the comments about her granddaughter's brown skin made by her son-in-law's family (Jen 2000: 6). She also comments that their "talk is like this sometimes, going around and around like a Christmas-tree train" (Jen 2000: 6). Therefore, she decides to put a stop to it by saying: "Maybe John is not her father" (Jen 2000: 7). Thus, she almost causes a "train wreck" (Jen 2000: 7). Finally, it leads to the following outcome: "No one ever mentioned the word brown to her again" (Jen 2000: 7).

In the story "Chin", a Chinese immigrant family and an American family live next door. The story is narrated by an American boy. Having the Chinese immigrant family next door makes him think about the things that he has never considered before and, as Derrida says, the arrivant becomes surprised (Derrida 1993: 34) by the Chinese family. The narrator starts to wonder "why everybody suddenly had to have a special food" (Jen 2000: 107). Before he met the Chinese, nobody in his neighbourhood 
Sandra Josipović: The Transformation of the Immigrant's Identity...

had had special food, "unless you wanted to count fries." (Jen 2000: 107). The boy says that the Chinese "were definitely proliferating" (Jen 2000: 107) in his neighbourhood, thus implying that the ethnic structure of their neighbourhood is undergoing a change and the neighbourhood sees this new family as someone who calls into a question the borders of their own home and their identity. This is probably why a cherry bomb was thrown into the Chinese family's kitchen (Jen 2000: 108). And also the narrator of the story wants to know why everybody starts asking what his family is. Nobody asked him that before (Jen 2000: 107). The question of what his family is could refer to race, because the young boy starts answering that question by saying: "Vanilla" (Jen 2000: 107).

Derrida also says: "Nor is the arrivant a legislator or the discoverer of a promised land. As disarmed as a newly born child, it no more commands than is commanded by the memory of some originary event where the archaic is bound with the final extremity [...]" (Derrida 1993: 34). In the story "In the American Society", Ralph Chang is a successful owner of the restaurant. But at one point in his life, he starts seeing himself as a "mandarin" and treating his employees as if they were his subjects and then his business starts going downhill. He starts imitating his grandfather's relationship with his village in China (Feddersen 2001: 199). He begins to lose employees who only want a job from him, they do not want to be his servants/ slaves (Jen 2000: 116). He asks cooks and busboys to fix the radiators, he even asks his headwaitress to scratch his back (Jen 2000: 116). Ralph Chang obviously retains at the back of his mind some primary code of his old country, or, as Derrida says, the memory of some ancient event rules his life (Derrida 1993: 34). The way Ralph Chang behaves also goes hand in hand with what Edward Said says:

Appeals to the past are among the commonest of strategies in interpretations of the present. What animates such appeals is not only disagreement about what happened in the past and what the past was, but uncertainty about whether the past really is past, over and concluded, or whether it continues, albeit in different forms, perhaps (Edward Said 1994: 3).

For Ralph Chang the past is very much alive. And this can be said for some other characters in Jen's stories. For example, the old lady in "Who's Irish?" very often refers to the past. She has the flashbacks of her days in China and her first days in America. Looking back on her life in China, she 
says, "We talk about whether life is bitter or not bitter" (Jen 2000: 8), or she remembers when she had her restaurants in America: ".... and in our restaurant, busboys and cooks all afraid of me too. Even the gang members come for protection money, they try to talk to my husband" (Jen 2000: 3). In "House, House, Home", Pammie also goes back in her mind to the events that influenced her as a child. Pammie thought her childhood "had been miserable" (Jen 2000: 134) because she was "margarinized" (Jen 2000: 134), as her babysitter put it wrongly instead of saying that Pammie was marginalized for being Asian.

\section{The immigrant and the question of hospitality}

When it comes to Derrida's conception of hospitality, he seems to go back and forth between conditional and unconditional hospitality, showing us what unconditional or absolute hospitality is and at the same time making a point how difficult, even impossible, it is to attain it, which is illustrated in some of Gish Jen's stories. Derrida defines absolute hospitality:

[...] absolute hospitality requires that I open up my home and that I give not only to the foreigner, but to the absolute, unknown, anonymous other, and that I give place to them, that I let them come, that I let them arrive, and take place in the place I offer them, without asking of them either reciprocity (entering into a pact) or even their names (Westmoreland 2008: 6)." Derrida also claims that hospitality is "unconditional but without sovereignty (Westmoreland 2008: 3).

Derrida concludes that (conditional) hospitality cannot be "without sovereignty of oneself over one's home, but since there is also no hospitality without finitude, sovereignty can only be exercised by filtering [...] and doing violence (Westmoreland 2008: 5-6)". Westmoreland concludes: "Absolute hospitality can only exist as unlimited, as not being within the parameters of laws and concepts. The conditions for such hospitality are both the conditions for its possibility and its impossibility" (Westmoreland 2008: 4).

In the story "Who's Irish?" the daughter offers her mother conditional hospitality, implying that the mother has to abide by her daughter's rules if she wants to live in her daughter's house. The daughter defends the 
Sandra Josipović: The Transformation of the Immigrant's Identity...

sovereignty of her home. On the other hand, this conditional hospitality turns her mother into an occupier or invader. The daughter feels that her mother invades her home by refusing to respect the daughter's rules: not to spank Sophie, not to criticize John, the son-in-law. The old lady asserts her own authority and does not give in to her daughter, telling her: "Don't tell me what to do" (Jen 2000: 9) and "I am not your servant. Don't you dare talk to me like that" (Jen 2000: 9). The daughter feels threatened by such an attitude and feels that her mother invades her space, oversteps her boundaries and undermines her authority in her own house. The situation reaches the critical point when her husband John expresses his dissatisfaction with the fact that the grandmother has spanked his daughter, saying: "And I'm not the only one with scary family patterns" (Jen 2000: 10). As Derrida says, the hospitality which is not absolute comes with some conditions that have to be fulfilled and it also presumes the sovereignty of the host's home and in order to retain that sovereignty, the host resorts to some kind of violence (Westmoreland 2008: 5-6). In the story, the daughter exercises some sort of violence over her mother by forcing her mother to move out because the daughter "doesn't want to end up divorced" (Jen 2000: 14). Westmoreland asks, "Should one demand that his guest be able to communicate in a foreign language?" (Westmoreland 2008: 5), which is according to Derrida "the first violence to which foreigners are subjected" (Westmoreland 2008: 5). The old woman does make an effort to learn the English language, in that way fulfiling one of the conditions of the hospitality she was given in America and in her daughter's home. When the old lady came to America, she couldn't speak English, she had to learn it in order to have a productive life and her own business. In her daughter's home, the old lady learns some new words, such as "supportive" (Jen 2000: 5), saying "we do not have this word in Chinese." (Jen 2000: 5) and "creative" (Jen 2000: 8), commenting that this is "another word we do not talk about in China" (Jen 2000: 8).

In the story "House, House, Home", for Pammie, the American hospitality has come with many conditions ever since she was a little girl. Pammie is an Asian American and when she was young, her babysitter told her that "if she wanted to survive the 1990s, she should not to use the word oriental, except for rugs" (Jen 2000: 134). She has always felt like an outsider. (Jen 2000: 188) Sven, her husband, and Pammie even argue over who is more genuinely an outsider, "he who had the vision and the will to refuse an acceptance that was his birthright, or she who had been born 
on the margin and slowly earned a conditional pass" (Jen 2000: 188). In Pammie's opinion Sven is "an elective outsider" (Jen 2000: 189) and she wonders if he could ever know "what it was like to be the other kind of outsider" (Jen 2000: 189).

In "House, House, Home", Sven is a host who has some conditions for his wife to fulfil. For example, he is disappointed because "she didn't know more about herbs" (Jen 2000: 165), and "he had encouraged her to buy and wear Chinese dresses" (Jen 2000: 165). She suspects that Sven sees her class as inferior (Jen 2000: 156), thus acknowledging the difference between them. In this story, neither is Sven a perfect or absolute host in their marriage nor are her parents perfect hosts to Sven as their son-in-law because all of them offer only conditional hospitality. As I have already mentioned, Derrida thinks the host has to be the master of his house if he wants to be hospitable, but that rules out the possibility of absolute hospitality and introduces possible violence (Westmoreland 2008: 5-6). Sven finds her parents' hospitality intrusive, even violent, and this conclusion results in his refusal to visit them. Sven "even didn't like being compelled to eat at dinnertime" (Jen 2000: 161) at their (her parents') place, saying it is "controlling" (Jen 2000: 161) and a "friendly hostility" (Jen 2000: 161). Pammie explains: "My parents came from a culture acquainted with famine. It's a form of selflessness to share their most precious resource" (Jen 2000: 161). Sven replies to that: "But one has no choice as to whether one accepts their hospitality. They don't listen to no. They ride gangbusters over one's boundaries. It's a naked coercion" (Jen 2000: 161). Pammie's identity is divided between the Chinese customs and traditions she was taught as a young girl and her American husband and his way of life and habits. Pammie is very much attached to her family, and she spends a lot of time buying and wrapping gifts for them. Sven asks her once: "Is that how you want to spend your life, trying to remember and please?" (Jen 2000: 154) She comes from a family "that thought mostly about bills" (Jen 2000: 139) and "She had grown up considering the optimum use of every dollar and every hour" (Jen 2000: 140). Contrary to what she was taught, "Sven did not see why they should not sleep in the living room. Sven did not see why people should not come in and out at all hours. Sven did not see why he should not wear other people's clothes" (Jen 2000: 139). 
Sandra Josipović: The Transformation of the Immigrant's Identity...

\section{Gish Jen's Chinese culture-specific concepts and words in literary translation}

In her stories, Gish Jen uses some Chinese culture-specific concepts, loan words and expressions and her protagonists very often do not speak grammatically correct English and they cannot spell. All these could present a challenge when translating her work into Serbian.

When it comes to the translation of loan words, Mona Baker writes: "The use of loan words in the source text poses a special problem in translation" (Baker 2011: 22). She suggests several possible solutions to this problem: "translation by a more general word" (Baker 2011: 23), "translation by a more neutral/less expressive word" (Baker 2011: 25), "translation by cultural substitution" (Baker 2011: 29), "translation by paraphrase using a related word" (Baker 2011: 36), "translation by paraphrase using unrelated words" (Baker 2011: 38), "translation by omission" (Baker 2011: 42), "translation by illustration" (Baker 2011: 43), "translation using a loan word or loan word plus explanation" (Baker 2011: 33). Mona Baker explains: "This strategy is particularly common in dealing with culturespecific items [...] Following the loan word with an explanation is very useful when the word in question is repeated several times in the text" (Baker 2011: 33). The translation strategy that includes "translation using a loan word or loan word plus explanation" (Baker 2011: 33) could very well work when translating some loan words in Gish Jen's stories because they are culture-specific items and because she herself gives explanation for some loan words in the text and some loan words are repeated several times in her stories.

Gish Jen introduces the following loan words in her stories: "pad thai" (Jen 2000: 4), "go shu-shu", the author explains in the text that it means 'to pee' (Jen 2000: 8), "lao taitai", the author herself explains it means 'little old ladies' (Jen 2000: 63, 64, 68, 69, 71, 73), "kowtow" (Jen 2000: 64, 65), a doctor "diagnosed Duncan, via pulse, as too yang" (Jen 2000: 77), "shou shou", the author herself explains it means 'skinny monkeys' (Jen 2000: 121), "a silver Chinese qipao" (Jen 2000: 162), "ma fan", the author explains in the text that it means 'making trouble' (Jen 2000: 197).

The author uses some English words and expressions which refer to the traditional and contemporary Chinese cultural concepts and the translation of these words and expressions could be accompanied by an explanation in a footnote because some readers are probably not familiar 
with the following even when they are translated into a target language: "Opium War" (Jen 2000: 4), "hoisin sauce" (Jen 2000: 5), "Chinese age" (Jen 2000: 5), "Long March" (Jen 2000: 50), "Cultural Revolution" (Jen 2000: 52, 57, 76), "Red Guards" (Jen 2000: 52, 57), "Mao jackets" (Jen 2000: 52), "bound feet" (Jen 2000: 63), "mung bean soup" (Jen 2000: 77), "Dragon's Well tea" (Jen 2000: 204).

Some immigrants in Gish Jen's story, particularly the first-generation immigrants, do not learn the language well and they are not fully proficient in its grammar. It can be a challenge to translate into Serbian the grammatically incorrect English language spoken by the old woman in "Who's Irish?": "[...] they are come to eat." (Jen 2000: 3), "she is handle everything [...]" (Jen 2000: 4), "She never go in the sun [...]" (Jen 2000: 6). The story "Duncan in China" can be challenging for a translator because it is about the American Chinese who comes to China to visit the country of his ancestors and to teach English to the Chinese, so in the story there are many mistakes made by the Chinese protagonists: "Must we have to practice English?" (Jen 2000: 58), "I catch your meaning." (Jen 2000: 66), "Now he has no any girlfriend" (Jen 2000: 66), "What you say?" (Jen 2000: 78), "You see his English how good" (Jen 2000: 78).

In the story "In American Society", there are some English words that are not written correctly in the letter written by former employees to their boss who posted bail for them so that they could be released from prison: "[...] Plese to excus us. People saying the law in America is fears like dragon [...] We hope some day we can pay back the rest bale. You will getting intrest, as you diserving, so grat a boss you are [...] In the next life you will be burn in rich family, with no more pancaks" (Jen 2000: 125).

In literary translation, a strategy for dealing with grammatically incorrect structures and errors used intentionally in the source text is given by Jeremy Munday, who says: "The translator should first determine what the function is: perhaps to indicate an uneducated speaker and to try to find some way of recreating that in the target language by also producing some incorrectness or linguistic signals of uneducatedness" (Daničić and Josipović 2015/2016: 178). He explains further on: "Look at the function: If the function is to indicate that the speaker has made an error because they don't have the education to understand or to make a correct selection, you are going to have to reproduce that in the target language" (Daničić and Josipović 2015/2016: 178). 
Sandra Josipović: The Transformation of the Immigrant's Identity...

Learning the language of the country he is coming to is one of the conditions an immigrant has to fulfil if he wants to find his place in the sun in a new country. Therefore, language is one of the elements that also makes unconditional hospitality something which is almost unattainable. Derrida concludes,

When (conditional) hospitality is given, it is accompanied with lawsthe rules and codes of language, which are shared among human beings. Common hospitality involves linguistic communication, which requires the distinction between individuals to be stripped away, and cancels the possibility of having an unconditional hospitality (Westmoreland 2008: 5).

\section{Conclusion}

As it can be seen, Gish Jen writes about the Chinese immigrants who come to America, whose identity is transformed when they come into contact with the American culture and society, but at the same time they never fully relinquish the elements of their Chinese culture and tradition. This is the process in which the Chinese and American cultures touch, interact, exchange words, cultural concepts and elements, thus proving Edward Said's belief that culture is a question of cultural borrowings, common experiences and interdependencies (Said 1994: 217). These Chinese immigrants are arrivants or newcomers who not only change their own lives, but also the lives of their hosts. This exchange and interaction between cultures presupposes the existence of hospitality. As far as hospitality is concerned, in Jen's stories we see the examples of what Derrida calls conditional hospitality (Westmoreland 2008: 5-6) with immigrants who have to fulfil certain conditions imposed by their hosts who do not intend to abandon the conditions of their hospitality. Therefore, unconditional hospitality can be a goal worth striving for, but for Gish Jen's protagonists it is difficult and almost impossible to accomplish such a goal. 


\section{References}

Andrejević, T. (2011). Understanding the Chinese Mentality - Some Basic Hints. In: Ž. Adamović et al. (eds.), I International Symposium - Engineering Management and Competitiveness (EMC2011) - Proceedings, Zrenjanin: University of Novi Sad Technical Faculty "Mihajlo Pupin" Zrenjanin, Republic of Serbia, 281-287.

Baker, M. (2011). In Other Words. London: Routledge.

Daničić, M. and S. Josipović (2015/2016). The Translator Is Not Just an Innocent Mediator. Philologia, 175-179.

Derrida, J. (1993). Aporias. Stanford: Stanford University.

Feddersen, C. R. (2001). Gish Jen. In: E. Fallon et al. (eds.), A Readers's Companion to the Short Story in English, Westport, Connecticut: Greenwood Press, 196-209.

Jen, G. (2000). Who's Irish? New York: Vintage Books.

Reverso: Online dictionary: French-English translation of words and expressions, definition, synonyms, accessed April 16, 2016, http:// dictionary.reverso.net/french-english/arrivant

Said, E. (1994). Culture and Imperialism. New York: Vintage Books.

Sokolowski, J. (2012). The Limits of Hospitality in Gish Jen's The Love Wife. The Journal of Transnational American Studies, 4(1), accessed April 16, 2016, http://scholarship. org/uc/item/6v8636jz.

Westmoreland, M. (2008). Interruptions: Derrida and Hospitality. Kritike: An Online Journal of Philosophy 2(1):1-10, accessed April 16, 2016, http:// www.kritike.org /journal/issue_3/ westmoreland_june2008.pdf. 